\title{
Off-page SEO and link building: General strategies and authority transfer in the digital news media
}

\author{
Carlos Lopezosa; Lluís Codina; Carlos Gonzalo-Penela
}

Nota: Este artículo se puede leer en español en:

http://www.elprofesionaldelainformacion.com/contenidos/2019/ene/09_es.pdf

How to cite this article:

Lopezosa, Carlos; Codina, Lluís; Gonzalo-Penela, Carlos (2019). “Off-page SEO and link building: General strategies and authority transfer in the digital news media". El profesional de la información, v. 28, n. 1, e280107. https://doi.org//10.3145/epi.2019.ene.07

Article received on June $15^{\text {th }}, 2018$ Approved on December $12^{\text {th }}, 2018$

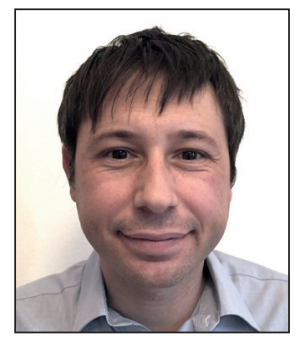

\section{Carlos Lopezosa $\bowtie$}

http://orcid.org/0000-0001-8619-2194

Pompeu Fabra University

Department of Communication

Roc Boronat, 138. 08018 Barcelona, Spain

carlos.lopezosa@upf.edu

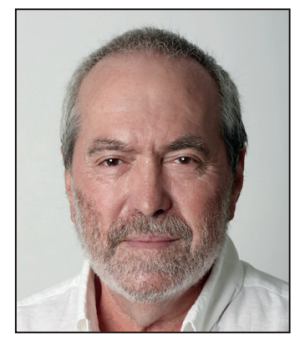

\section{Lluís Codina}

http://orcid.org/0000-0001-7020-1631

Pompeu Fabra University

Department of Communication

Roc Boronat, 138. 08018 Barcelona, Spain

Iluis.codina@upf.edu

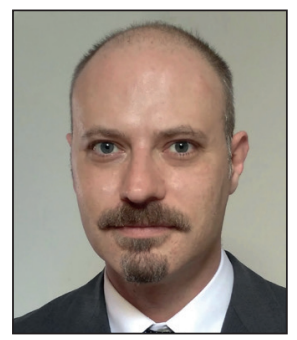

\section{Carlos Gonzalo-Penela}

https://orcid.org/0000-0002-3380-6823

Pompeu Fabra University

Department of Communication

Roc Boronat, 138. 08018 Barcelona, Spain

carlos.gonzalo@upf.edu

\begin{abstract}
In recent years, a number of digital news media outlets have begun to include paid links in their content. This study seeks to identify and analyse this content whose sole purpose is to improve the website authority of the advertisers and their search engine rankings. To do so, it employs two basic methodologies: first, it undertakes a systematic review of off-page SEO practices, the digital press and native advertising; and, second, it reports a case study based on the identification and analysis of 150 news items that contain specially commissioned links resulting from a commercial transaction. The study provides evidence of a new revenue stream for the digital news media, one that is not clearly disclosed and which is based on the sale of links. The article includes a discussion of the case study findings, and presents future guidelines for the use of paid links based on the emerging concept of 'native advertising'.
\end{abstract}

\section{Keywords}

Digital news media; Online journalism; Digital journalism; SEO; Off-page SEO; Web positioning; Link building; Native advertising; Journalism ethics. 


\section{Introduction and study goals}

This study examines a new activity being practiced by the digital news media involving the sale of links and aimed at improving the web positioning of the sites that receive them. These links are embedded in articles that are written solely with this purpose in mind. In some instances, the content of the articles is actually provided by the buyer of the links. It is, therefore, a form of advertising which, as it is not clearly disclosed, can easily be confused with editorial content.

Such content can give rise to three types of problem:

- as it is produced with the sole purpose of serving as a link vector, its quality is of secondary importance and, moreover, it responds not to journalistic criteria but rather to those of advertising;

- as it is not clearly identified as sponsored content, it threatens to undermine professional ethics, which requires the unambiguous separation of this type of content from editorial content.

- as it is presented in a non-transparent fashion, not only is the public unaware of such practices, but many studies (and experts) of the digital media are also unaware of it.

If, in the current digital information ecosystem, this is one of the engines of content creation, then experts undisputedly have an incomplete picture of this ecosystem if they are unfamiliar with this practice.

We are dealing with a form of advertising that, as it is not clearly disclosed, can easily be confused with editorial content

To understand the emergence of this activity, in this study we examine the SEO strategy that underpins it, based on what is known as 'link building'. More specifically, the goals of this study can be stated as follows:

- To analyse and characterise a new line of activity in the digital news media centred on link buying/selling and to identify the actors involved.

- To classify the content published as a result of this activity and to examine its implications for off-page SEO strategies.

- To provide guidelines for the possible improvement of this activity by developing a set of best practices modelled on so-called native advertising.

In keeping with these objectives, we address the following research questions:

- What are the main characteristics of this new line of activity centred on link buying/selling in the digital news media and who are its main actors?

- What are the main characteristics of the content published as link vectors?

- Is it possible to develop a set of best practices for this activity based on native advertising in order to improve it?

\subsection{Methodology}

The following two basic methodologies were employed in conducting this study:

- Systematic literature review (Hart, 2008; Booth; Papaionnou; Sutton, 2012) of the articles listed in the bibliography of this paper, based on a prior consultation of the Scopus, Web of Science, Lista and Communication Source databases. We also consulted the most authoritative professional sources in relation to SEO -including Search Engine Journal and Search Engine Land- and native advertising -including the Native Advertising Institute and the Nieman Reports-.

- Case study research (Yin, 2014) involving the identification, selection and classification of a set of 150 news items, published by three digital news media outlets and originating from link buying/selling.

The results of the systematic literature review are presented first followed by the case study findings. The former enable us to outline the main characteristics of off-page SEO strategies, which are the origin of this practice; the latter allow us to classify the products of this activity.

\section{Off-page SEO}

It is worth recalling that Google was the first search engine to apply a technique based on hyperlink (i.e. the links between web pages) analysis to determine the relative importance of all pages on the World Wide Web.

For analyses of this type, the inventors of Google based their work on citation analysis in the academic world and its corresponding impact factor. In this way, they designed a metric-PageRank- that serves to express the results of such an analysis (Brin; Page, 2000).

Given its enormous efficacy, Google has had an enduring influence on the way in which search engines display their results pages, with all of them adopting the same basic idea (Kleinberg, 1998; Lewandowski, 2012; Giomelakis; Veglis, 2015). The reason for its widespread adoption is that it provided the first genuinely efficient response to all the challenges posed by Internet searches (Gonzalo-Penela; Codina; Rovira, 2015), although initially no firm in the search engine sector seemed to realise. 
More specifically, the new idea developed by Google was the following: instead of calculating the relevance of each page exclusively in terms of its intrinsic characteristics-including, for example, the number of times the keyword appears-, it also took into account its extrinsic characteristics, most notably, the number and quality of links it receives (Harry, 2013).

What was the underpinning rationale? In broad terms, given two pages addressing the same theme, the more important of the two is considered to be the one that receives the greater number of backlinks from websites which, in turn, are highly linked (Brin; Page, 2000; Thelwall, 2004; Gonzalo-Penela, 2006).

Here, the key point is that part of a page's PageRank can be transferred to other pages if they are linked to it. PageRank is also a measure of a page's authority in the same sense that a journal's impact factor is a measure of its authority.

In this way, the net effect of these links -indistinctly known as backlinks, inbound links or external links- is to transfer authority from the page that points to the linked page, improving its visibility in the search engines (Crowe, 2017; Giomelakis; Veglis, 2016).

Consequently, the number and quality of the links that link to a website are an indicator of its essential relevance, as well as being one of the most influential positioning factors (Fishkin, 2016; García-Carretero et al., 2016). It is not surprising, given these circumstances, that firms' SEO managers seek to implement link building strategies (Gonzalo-Penela, 2006; Serrano-Cobos, 2015). This, in turn, has led to two major branches of SEO:

- On-page SEO: actions to optimize web page content.

- Off-page SEO: actions to obtain backlinks, that is link building.

Several link building procedures have been developed (Monterde, 2016; Publisuites, 2018), among which two stand out:

- Natural or editorial link building: this is based on a similar logic to that of the impact factor of academic articles, whereby a high quality article is one that will be highly cited, thus establishing itself as an article of great authority. In the case of the web, this type of link building is achieved by creating high quality content.

- Strategic link building: this is a proactive practice that requires direct contact between the website manager and the author of another site to which a link is requested. If performed on a massive scale, Google, Bing, Yahoo, Yandex, etc. are able to identify patterns of unnatural links, and if so, penalize those web sites by pushing them down the search result rankings, or even excluding them from their indexes

The main goals, therefore, of off-page SEO professionals are (Cámaras-León, 2018; Rowe, 2018):

- to search for and obtain a large number of backlinks;

- to multiply the strength of backlinks by ensuring that the sites from which the links originate are in turn highly linked.

There exist various websites where it is possible to obtain free backlinks. Primarily they can be obtained from web profiles, forums, social networks, blogs 2.0, comments on websites/blogs, wikis, content aggregators, directories, newspapers, third-party websites, etc., and of course from other websites (Cooper, 2012).

From a technical point of view, but with far-reaching implications for the matter in hand, there are two types of backlink: dofollow links (also known as follow), and nofollow links (Dean, 2018).

Both types of link are identified by means of the corresponding labelling of the source code (not visible on the page). They can be explained as follows:

- dofollow links fulfil the original function of hyperlinks, that is, they link related themes. Due to their editorial nature, Google considers them a way of transferring authority to the linked website, and the amount of authority or of PageRank transferred depends on the quality or authority of the page that creates the link. Dofollow means that Google will follow the link and attribute PageRank to the page that receives it. In theory, dofollow links are limited to editorial links. Dofollow links do not have a brand. In other words, a standard link, without any additional brand, is a dofollow link.

- nofollow links, on the other hand, include a source code tag that tells searchers that this link cannot be used for PageRank. It is a code that informs search engine robots not to follow the link (hence its name). Since they correspond to advertising links, the transmission of authority in this case is zero.

\subsection{Anchor text}

The links are made up not only of the corresponding URL, but also of a text known as the anchor text (González-Villa, 2017). This is the portion of the text that activates the link on the web page from which it originates.
Nofollow links include a label that tells the search engines they cannot be used to transfer authority because they are advertisements 
For Google, the anchor text forms part of the content of the linked site, and it is used to determine whether that site is relevant for the keyword contained in the anchor text (Figure 1).

In short, we should stress the following: the authority of the site from which a link originates, the link's anchor text and the context in which that link is included are the most important elements of link building.

Figures 1 and 2 illustrate the main concepts associated with links, as presented above.

Figure 1 shows the structure of a link using the source code. It can be seen that:

- the link's destination, that is, the page that will open in the browser if the user clicks on it is https://es.unesco.org

- the anchor text is Unesco.

Peace is one of the missions of $<$ a href="https://es.unesco.org/">Unesco</a $>$.

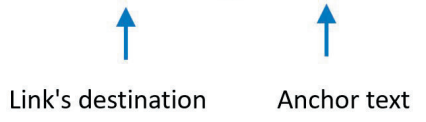

Figure 1. Source code of a dofollow type link

This is a dofollow link because it does not include any additional coding (see Figure 2). For this reason, this link transfers PageRank or authority to the Unesco page. If the page containing this link belongs to a leading digital newspaper, such as The New York Times, the authority transferred will be very high. Moreover, Google will understand that the Unesco keyword in the anchor text is part of the content of the destination page.

Figure 2 shows the structure of a nofollow link, since it incorporates the 'rel' attribute, with the nofollow value. Due to this attribute, the link does not transfer authority to the (fictitious) destination page Store. In this case, the authority of the page containing the link is of no significance. Moreover, because of this attribute, Google will not follow the link and will not transfer any value.

Don't forget to do your shopping at <a href="https://store.com/" rel="nofollow">Store</a>.

Nofollow code

Figure 2. Source code of a nofollow type link

\section{Hyperlink buying/selling sector}

Any human activity that can give rise to a supply and demand relationship will eventually generate a market. Here, news media websites have something (offer) that the SEO managers of other sites need (demand), namely, backlinks of great authority.

Hence, it was only a matter of time before SEO managers began to explore the possibility of buying links in the digital news media. To mediate in this relationship, a number of intermediaries have emerged to act as go-betweens for the website managers that need backlinks and the online news media.
The authority of the site from which a link originates, the link's anchor text and the context in which that link is included are the most important elements of link building

Given this change in the digital information ecosystem, one of the objectives of this study was to identify the leading firms operating in this sector. Although it is impossible to determine exactly how many companies are operating in Spain, based on our monitoring of professional forums, social networks and other sources regularly used by the sector's professionals, we believe that those shown in Tables 1 to 5 are, by far, the most important.

To outline the main characteristics of these intermediaries, we present their principal features in the following data files. All data are derived from their respective websites (Tables 1 to 5). 
Table 1. PrensaRank

\begin{tabular}{|l|l|}
\hline Name & PrensaRank \\
\hline URL & https://prensarank.com \\
\hline Description & $\begin{array}{l}\text { Its website claims they have 3,660 customers, } 408 \text { newspapers from which they can obtain links, and (as of February } \\
\text { 2018) they had sold 30,024 articles to the news media. }\end{array}$ \\
\hline Digital news media & $\begin{array}{l}\text { On registration the user obtains a link purchase interface. We identify } 305 \text { newspapers, distributed geographically as } \\
\text { follows: Andorra: } 1 \text { newspaper; Saudi Arabia: } 1 ; \text { Argentina: } 9 ; \text { Chile: 4; Spain: 236; USA: 2; Mexico: 45; Nicaragua: } 1 ; \text { Peru: } \\
\text { 1; Portugal: } 1 ; \text { United Kingdom: 2; Venezuela: } 2 .\end{array}$ \\
\hline Themes & $\begin{array}{l}\text { Current affairs; Love, weddings, relationships, and couples; Betting and casinos; Art, decoration and design; Film and tele- } \\
\text { vision; Cooking and gastronomy; Dating; Sports; Economics and politics; Education and culture; Company (advertising); } \\
\text { Home, decoration and DIY; Humour and leisure; Computers and technology; Games and video consoles; Marketing and } \\
\text { SEO; Pets and nature; Music and shows; Fashion and beauty; Cars; Women, babies, and children; Others; Religion, mysti- } \\
\text { cism and esotericism; Health; Estate agency services; Sex shops; Sexuality; Tarot; Travel, hotels and tourism. }\end{array}$ \\
\hline Maximum price for link & \begin{tabular}{l}
$€ 950$ \\
\hline
\end{tabular} \\
\hline
\end{tabular}

Table 2. Unancor

\begin{tabular}{|c|c|}
\hline Name & Unancor \\
\hline URL & https://www.unancor.com \\
\hline Description & Its website claims (as of February 2018) they have 6,000 customers and 500 newspapers from which they can obtain links. \\
\hline Digital media & $\begin{array}{l}\text { On registration the user obtains a link purchase interface. We identify } 431 \text { newspapers, distributed geographically as } \\
\text { follows: Germany: } 53 \text { newspapers; Argentina: 39; Canada: 1; Chile: 13; Colombia: 6; Costa Rica: 1; El Salvador: 1; Arab } \\
\text { Emirates: 1; Spain: 213; USA: 18; France: 17; Italy: 1; Morocco: 1; Mexico: 44; Monaco: 1; Nicaragua: 1; Panama: 1; Peru: } \\
\text { 2; Uruguay: 3; Venezuela: } 5\end{array}$ \\
\hline Themes & $\begin{array}{l}\text { All these newspapers are associated with one or more of the following topics: Art and culture; Health and sport; Econo- } \\
\text { mics and business; Education; Home, decoration and DIY; Cooking and recipes, gastronomy; Computers, technology, } \\
\text { mobiles and apps; Marketing (offline and online); Nature (animals and plants); Cars and motorcycles; Cinema, TV and } \\
\text { music; News and politics; Travel and tourism; Others; Fashion and beauty; Erotica; Love, relationships, couples; Services } \\
\text { (locksmiths, home improvements, plumbers, etc.); Legal; Children; Tarot }\end{array}$ \\
\hline Maximum price for link & $€ 10,000$ \\
\hline
\end{tabular}

Table 3. Publisuites

\begin{tabular}{|c|c|}
\hline Name & Publisuites \\
\hline URL & https://www.publisuites.com/es \\
\hline Description & $\begin{array}{l}\text { Its website claims they have } 54,967 \text { users and } 478 \text { newspapers from which they can obtain links. As of February } 2018 \text {, } \\
\text { they had sold 39,334 articles to the news media and blogs. }\end{array}$ \\
\hline Digital media & $\begin{array}{l}\text { On registration the user obtains a link purchase interface. We identify } 478 \text { newspapers, distributed geographically as } \\
\text { follows: Argentina: } 19 \text { newspapers; Australia: 1; Bolivia: 1; Brazil: 4; Chile: 6; Colombia: 4; El Salvador: 1; Spain: 304; USA: } \\
\text { 3; France: 26; Honduras: 1; Italy: 70; Jersey: 1; Mexico: 14; Nicaragua: 1; New Zealand: 1; Panama: 1; Paraguay: 1; Peru: 6; } \\
\text { Portugal: 3; United Kingdom: 1; Dominican Republic: 1; Senegal: 1; South Africa: 1; Venezuela: } 6 .\end{array}$ \\
\hline Themes & $\begin{array}{l}\text { All these newspapers are associated with one or more of the following topics: Betting, casinos and lotteries; Celebri- } \\
\text { ties; Cooking, recipes and gastronomy; Trivia; Sports; Economy; Education and training; Entrepreneurs and SMEs; Com- } \\
\text { puters and programming; Literature and culture; Music and radio; Marketing, SEO and social platforms; Miscellaneous; } \\
\text { Fashion and accessories; Cars and motorcycles; Nature and ecology; News; Leisure and free time; Politics; Health; } \\
\text { Technology; Mobile telephones and apps; Travel and tourism. }\end{array}$ \\
\hline Maximum price for link & $€ 1,943$ \\
\hline
\end{tabular}

Table 4. RT Gopress

\begin{tabular}{|l|l|}
\hline Name & $\boldsymbol{R}$ T Gopress \\
\hline URL & https://rtgopress.com \\
\hline Description & $\begin{array}{l}\text { Its website claims it is the most economically competitive Seo MarketPlace, Social Media and Growth Hacking firm in } \\
\text { the market. They do not indicate how many newspapers or customers they have. }\end{array}$ \\
\hline Digital media & $\begin{array}{l}\text { On registration the user obtains a link purchase interface. We identify } 155 \text { newspapers distributed geographically as } \\
\text { follows: Argentina: } 3 ; \text { Mexico: } 26 ; \text { Spain: } 126 .\end{array}$ \\
\hline Themes & $\begin{array}{l}\text { All these newspapers are associated with one or more of the following topics: Current affairs; Stock market; Sports; } \\
\text { Economics; Gastronomy; Marketing; Cars; Tourism; News; Technology; Health; Video games. }\end{array}$ \\
\hline Maximum price for link & The website operates a price filter, but it appears not to be operative. \\
\hline
\end{tabular}


Table 5. Dofollow

\begin{tabular}{|l|l|}
\hline Name & Dofollow.es \\
\hline URL & http://dofollow.es \\
\hline Description & $\begin{array}{l}\text { While offering a similar service to the above firms, it operates differently. Thus, they offer what they call the dofollow } \\
\text { pack. The customer writes a press release including two links to its website (1 for a brand and the other a keyword) } \\
\text { and they undertake to publish the press release in four digital newspapers. }\end{array}$ \\
\hline Digital media & $\begin{array}{l}\text { Its website includes general, regional, and specialized newspapers of all types. They state that these media may vary } \\
\text { depending on availability. }\end{array}$ \\
\hline Themes & Unknown. \\
\hline Maximum price for link & $€ 339$ for its most complete package. \\
\hline
\end{tabular}

\section{Native advertising}

The general absence of studies examining the link buying/selling sector in the digital news media and, hence, the development of any guidelines for its self-regulation, leads us here to consider the possibility of applying best practices in the so-called native advertising industry.

The Native Advertising Institute defines native advertising as the use of paid ads that match the look, feel and function of the content of the platform in which they appear (Schauster; Ferrucci; Neill, 2016; Pollitt, 2018).

Native advertising consists of news items, reports and, in general, quality content, its effectiveness being based on credibility. These characteristics can be used to provide quality content to publications (Sweetser et al., 2016; Carlson, 2016). An essential point is that native advertising must present a branded message that allows readers to recognize not only the fact that it is sponsored content (Ferrer-Conill, 2016; Amazeen; Muddiman, 2017; Amazeen; Wojdynski, 2018), but also the logical intent of the advertisement to persuade and sell (Mathiasen, 2018).

As such, the idea is that the digital press should have a model for including sponsored content that allows it to be differentiated from their editorial content, and which, moreover, ensures it can be integrated naturally in the publication, maintaining a level of quality similar to that of the platform that hosts it (Cramer, 2016; Li, 2017; Batsell, 2018).

\section{Case study}

Having identified the key components and actors operating in the link buying/selling industry, we present our case study, which consists of a comparative analysis. We examined 150 news items that have been published as a direct result of the buying/selling of links. As such, we are dealing with content specially commissioned with the aim of including links to improve the website authority of the customers who purchase them.

To shed greater light on this procedure, we first explain how the whole process works. First, the customer contacts one of the link building firms described in the section above to purchase backlinks to its website from the digital news media. This news outlet then publishes content that includes links to the customer's website. In so doing so the process is terminated, following payment by the buyer at the price stipulated for receipt of backlinks. It should be stressed that what is purchased is the link or backlink and that the content is merely the vehicle in which it is included, which generally results in content unrelated to the newspapers normal editorial line.

To explore this market, we conducted an analysis whose object of study was three digital news media of medium to high importance.

Given the nature of this analysis, we do not explicitly identify the name of each news outlet, but rather describe them as accurately as possible using a series of data files (Tables 6 to 8). In these files we specifically incorporate the data provided by Alexa Rank, a ranking developed by Amazon, based on web traffic.

In addition, to lend greater credibility to the ranking of these three digital news media companies, we incorporate daily unique user data for each of the three websites. To do so, we used Site Worth Traffic, which measures website traffic providing unique and total user data, social network performance metrics, and a complete analysis of the site's evolution.

To select the news stories from the three media companies, we purchased three items from the Prensarank website (one item for each news media). Then, having
News media websites can offer backlinks of great authority 
Table 6. Digital news media company 1

\begin{tabular}{|l|l|}
\hline \multicolumn{2}{|l|}{ Media company $\mathbf{1}$ (MC1) } \\
\hline Media type & Generalist \\
\hline Country & Spain \\
\hline Alexa ranking & Ranked $252^{\text {nd }}$ in Spain (June 2018) \\
\hline Daily unique users & 69,782 \\
\hline
\end{tabular}

examined these news stories, we were able to identify a search pattern for each item, and with this to create what is known as its 'footprint': that is, a type of advanced search (Google, 2018) that allows the highly precise selection of well-characterized web page types.

In this way we identified three footprints that allowed us to locate 50 news items purchased from each of the three media companies. Each of these footprints, in the form of an advanced search equation, is constructed as follows (using the site search operator):

- site: MC1(media company 1 ) + name of link buying/selling company.

- site: MC2(media company 2) + the word "remitido" (or "press release").

- site: MC3(media company 3) + name of a news item contributor.

Having obtained the 150 news items (50 for each media company) by applying the respective equations, we were then able to isolate the following elements by responding to the six questions below, based on recommendations made by the Native Advertising Institute and the Nieman Reports:

- Is the news item specifically identified as sponsored content?

- Is the story reported newsworthy, that is, is the item directly linked to a breaking news story or current affairs?

- How many hyperlinks are included in each news item?

- Are the hyperlinks coherent with the content of the news item?

- Do the hyperlinks point to an authoritative website providing users with complementary quality information?

- What themes are the commissioned news items included in?

\section{Results}

Below, we first present our main findings. Next, we review our research objectives and questions in order to present our conclusions, and we finish with proposals for the development of new lines of research.

\subsection{Main findings}

From our study of the 150 news items commissioned in the three digital news media companies, the following results can be highlighted:

- News originating from the purchasing of a link is not clearly identified as sponsored content or advertising.

- The content does not describe or narrate a breaking news story or current affairs, that is, it is not a typical news story, but rather the content is timeless, generally involving recommendations and advice.

- The need to include the literal anchor text (the text that activates the link) as commissioned by the customer leads to errors of grammar and syntax in the writing of the content. The reason for this is that the authors opt to respect the keyword or phrase commissioned by the customer even if it does not fit with the syntax or phrase in which it is embedded.

- When a news item contains more than one link, the need to maintain two or more links in the same item for sites of distinct natures results in a lack of coherence between the links and the content of the news story.

Tables 9 to 11 show the results for each of the three digital news media companies in greater detail. 
Table 9. Results for MC 1

\begin{tabular}{|c|c|}
\hline $\begin{array}{l}\text { Are news items identified as sponsored } \\
\text { content? }\end{array}$ & $\begin{array}{l}\text { Identification somewhat ambiguous. Items are identified as a Communicado (or news release). } \\
\text { The headline is displayed in the following format: "News release: title of the story". }\end{array}$ \\
\hline Is the content newsworthy? & No. It is timeless involving recommendations and offering tips. \\
\hline $\begin{array}{l}\text { How many hyperlinks are included in each } \\
\text { item? }\end{array}$ & $\begin{array}{l}\text { Of the } 50 \text { items analysed: } \\
1 \text { item includes one hyperlink } \\
8 \text { items include two hyperlinks } \\
4 \text { items include three hyperlinks } \\
37 \text { items include four hyperlinks }\end{array}$ \\
\hline $\begin{array}{l}\text { Are the hyperlinks coherent with the } \\
\text { content? }\end{array}$ & $\begin{array}{l}\text { No. Most are shoehorned into the item; others use a syntactically incorrect generic anchor text. } \\
\text { In some of the items with more than one hyperlink, there is no thematic link between them. }\end{array}$ \\
\hline $\begin{array}{l}\text { Do the hyperlinks point to an authoritative } \\
\text { website providing users with complemen- } \\
\text { tary quality information? }\end{array}$ & $\begin{array}{l}\text { No. In general, hyperlinks point to websites that are not authoritative and, therefore, do not } \\
\text { provide noticeable added value for the user-reader. }\end{array}$ \\
\hline $\begin{array}{l}\text { What themes are the commissioned news } \\
\text { items included under? }\end{array}$ & $\begin{array}{l}\text { The main themes are business, the home, beauty, tourism, productivity, cars, weddings, fas- } \\
\text { hion, health, and decoration. }\end{array}$ \\
\hline
\end{tabular}

Table 10. Results for MC2

\begin{tabular}{|l|l|}
\hline $\begin{array}{l}\text { Are news items identified as sponsored } \\
\text { content? }\end{array}$ & $\begin{array}{l}\text { Ambiguous. Items are identified with a tag that reads Remitido (or news/press release) followed } \\
\text { by the headline. }\end{array}$ \\
\hline Is the content newsworthy? & No. It is timeless involving recommendations and offering tips. \\
\hline $\begin{array}{l}\text { How many hyperlinks are included in each } \\
\text { item? }\end{array}$ & $\begin{array}{l}\text { Of the } 50 \text { items analysed: } \\
10 \text { items include one hyperlink } \\
13 \text { items include two hyperlinks } \\
6 \text { items include three hyperlinks } \\
21 \text { items include four hyperlinks }\end{array}$ \\
\hline $\begin{array}{l}\text { Are the hyperlinks coherent with the } \\
\text { content? }\end{array}$ & $\begin{array}{l}\text { No. Most are shoehorned into the item; others use a syntactically incorrect generic anchor text. } \\
\text { In some of the items with more than one hyperlink, there is no thematic link between them. }\end{array}$ \\
\hline $\begin{array}{l}\text { Do the hyperlinks point to an authoritative } \\
\text { website providing users with complemen- } \\
\text { tary quality information? }\end{array}$ & $\begin{array}{l}\text { No. In general, hyperlinks point to websites that are not authoritative and, therefore, do not } \\
\text { provide noticeable added value for the user-reader. }\end{array}$ \\
\hline $\begin{array}{l}\text { What themes are the commissioned news } \\
\text { items included under? }\end{array}$ & $\begin{array}{l}\text { The main themes are work, recipes and gastronomy, business, cars, healthy living, gadgets, } \\
\text { cooking, fashion trends and styles, and fortunes and tarot. }\end{array}$ \\
\hline
\end{tabular}

Table 11. Results for MC3

\begin{tabular}{|l|l|}
\hline $\begin{array}{l}\text { Are news items identified as sponsored } \\
\text { content? }\end{array}$ & No. Items are presented as another news story, that is, as editorial content. \\
\hline Is the content newsworthy? & No. It tends to be timeless involving recommendations and offering tips. \\
\hline $\begin{array}{l}\text { How many hyperlinks are included in each } \\
\text { item? }\end{array}$ & $\begin{array}{l}\text { Of the } 50 \text { items analysed: } \\
17 \text { items include one hyperlink } \\
11 \text { items include two hyperlinks } \\
2 \text { items include three hyperlinks } \\
20 \text { items include four hyperlinks }\end{array}$ \\
\hline $\begin{array}{l}\text { Are the hyperlinks coherent with the } \\
\text { content? }\end{array}$ & $\begin{array}{l}\text { No. Most are shoehorned into the item; others use a syntactically incorrect generic anchor text. } \\
\text { In some of the items with more than one hyperlink, there is no thematic link between them }\end{array}$ \\
\hline $\begin{array}{l}\text { Do the hyperlinks point to an authoritative } \\
\text { website providing users with complemen- } \\
\text { tary quality information? }\end{array}$ & $\begin{array}{l}\text { No. In general, hyperlinks point to websites that are not authoritative and, therefore, do not } \\
\text { provide noticeable added value for the user-reader. }\end{array}$ \\
\hline $\begin{array}{l}\text { What themes are the commissioned news } \\
\text { items included under? }\end{array}$ & $\begin{array}{l}\text { The main themes are business, virtual spaces, tourism, music, health, cars, investments, holi- } \\
\text { days, problem pages, and travel. }\end{array}$ \\
\hline
\end{tabular}




\section{Discussion and conclusions}

\subsection{Discussion}

Link building strategies and link buying can greatly benefit both SEO companies in their bid to provide their clients' websites with greater authority, as well as news media companies as they seek to grow their revenue. However, without adequate regulation, users stand to suffer, being presented with poor quality content and information that do not respond to criteria of journalistic or editorial feeds, but rather to those of advertising.

Specifically, we have seen that in two of the three Spanish news media companies analysed some attempt is made to signal a divide between sponsored and editorial content, but such attempts are ultimately ambiguous.

Instead of identifying the content with an unmistakable tag indicating sponsorship or advertising, other labels are employed, such as comunicado (news release) or remitido (news/press release). This is better than nothing, but it remains nevertheless ambiguous. Comunicado or remitido are usual journalistic terms for referring to press releases that serve as the basis for perfectly valid editorial content, which is why these tags must be considered inadequate, albeit that they do represent some attempt on the part of the publication to indicate their actual content.

In contrast, one of the news media companies does not seek to make any distinction in content, which is a more serious matter.

In all three cases, readers may well think they are reading editorial content and, therefore, believe that the linked sites have been selected for their quality when in fact what they are reading is advertising or sponsored content.

Moreover, as their origin is not strictly editorial, the content tends to be largely superficial and to have little or no relationship with the linked sites.

These two closely related factors have a somewhat negative impact on the quality of the content of the news media companies. However, it is apparent that if we adhere to the Native Advertising model, the interests of all parties can be reconciled: Advertisers can obtain authoritative links, the content can be genuinely interesting - while at the same time being clearly identified as sponsorship - and the media can have a new model of sustainability.

\subsection{Conclusions}

To present the conclusions, we first go back to the study's initial objectives to consider how far they have been fulfilled. Then we do the same with the research questions.

\section{Objectives}

Objective 1. To analyse and characterise a new line of activity in the digital news media centred on link buying/selling and to identify the actors involved.

We have shown that a new model of economic activity has emerged based on link buying/selling and that this activity is becoming increasingly more commonplace, as demonstrated by our close monitoring of the sector over the last two years. As a result, the number of news media companies now included on the websites studied here (Prensarank, Unancor, Publisuite and RT Gopress) has experienced constant growth.

We have shown that this line of activity adds value to each party involved -the digital news media, the customers that buy links and the firms that act as intermediaries in the sales transaction- as it seeks to fulfil three main objectives:

- Providing a new revenue stream, albeit that for the time being it remains a fairly marginal stream for news media companies.

- Obtaining greater website authority and improving the visibility of the websites that buy backlinks.

- Generating revenue in the form of commissions to the intermediary firms dealing in hyperlinks.

Objective 2. To classify the content published as a result of this activity and its implications for off-page SEO strategies.

We have shown that the sector does not operate a system of self-regulation, since each of the three news media companies analysed applies different criteria. Furthermore, contrary to native advertising, the sponsored content does not conform to the look, feel and function of the content of the platform on which they appear.

Different degrees of ethical awareness can also be identified, since news media companies 1 and 2 at least go some way to specifically identifying this content (by labelling items as comunicados or remitidos), while company 3 avoids drawing any distinction between editorial and sponsored content. 
Objective 3. To provide guidelines for the possible improvement of this activity by developing a set of best practices modelled on so-called native advertising.

Based on native advertising regulations, an initial proposal of best practices for the writing of news items for link selling should consider the following guidelines:

- There should be a clear indication that the news story published is sponsored content or advertising - the distinction being that the latter is provided by the advertiser, the former by the news media company itself.

- The news item should match the look, feel and function of the content of the platform on which it appears.

- The information included in the commissioned news item should be newsworthy or, at least, useful for the reader, and should be based on current news stories. The news story ought to be written with the user in mind and should not be motivated solely by the hyperlink that has been purchased. Its features should serve not only the needs of the link buyers but also those of the readers.

- More than one link can be included in a news story provided there is a thematic connection between them that does not affect the story's overall coherence.

- The hyperlinks and their anchor texts must be orthographically and syntactically coherent with the text of the news item.

- As a rule, if the hyperlinks do not lead to an authoritative website that provides useful, complementary information to readers, then this link should not be added to editorial content. Instead, these links should be published in a section dedicated exclusively to sponsored content or advertising and separated from the newspapers' usual sections.

\section{Research questions}

Next, we return to the research questions posed at the outset to examine the responses obtained from the case study reported above.

Question 1. What are the main characteristics of this new line of activity centred on link buying/selling in the digital news media and who are its main actors?

We have shown that it is possible to both clearly identify and determine the characteristics of this line of activity in the news media centred on the acquisition of links and content that act as vectors for these links and content.

It is a business model in which the three main actors, i.e. the digital news media, their customers, and link buying intermediaries, all benefit. The news media and the intermediaries obtain an economic return, while the clients obtain greater web site authority and visibility. The loser in the activity is, however, journalistic quality and, with it, the readers of the news media.

Question 2. What are the main characteristics of the content published as link vectors?

The analysis shows that the news items identified in this case study present the following characteristics:

- They do not carry clear labels identifying their content as advertising or sponsored.

- They are timeless, focusing primarily on providing advice and basic recommendations on a huge variety of topics ranging from tourism, cooking, and cars, to investments, beauty, and technology, and many others.

- They can include up to four backlinks. These links are often shoehorned into the content, not only because they are poorly constructed in terms of their semantics but also because they link to websites that do not provide complementary quality information for their readers.

Question 3. Is it possible to develop a set of best practices for this activity based on native advertising in order to improve sector practices?

Here, we have taken the concept of native advertising as our reference because it can be considered to provide interesting precedents and, as such, to be a model for future regulations governing paid links in the digital press.

Broadly speaking, the news items in our sample point clearly to the need to develop a set of best practices, preferably so that the media companies can self-regulate themselves, rather than depend on an external regulator.

Digital news media readers deserve the highest degree of quality and transparency, characteristics that ultimately benefit the news media themselves, especially if we consider the acute crisis they are currently experiencing. It is important that the media generate additional revenue streams, which is why this line of business should be understood as being both necessary and timely.

However, the sector's legitimacy calls for a highly transparent and stringent system of self-regulation and, here, we have identified some of the essential elements that need to be taken into consideration in developing such a system. The 
key idea in the process is that the transfer of authority effected by link buying/selling should not negatively impact the content quality or the reading experience of the news media that participate in this business model. Additionally, maximum transparency must be guaranteed at all times.
The transfer of authority effected by the link buying/selling should not negatively impact the quality or the reading experience of the news media involved in this business model

\section{Future research}

More ethical studies need to be undertaken within the digital news media to determine best practices for the selling of commissioned news items and hyperlinks. In this way it should be possible to reconcile the sector's legitimate interest for sponsorship or advertising revenue with the interests of their users who consume news and with their right to receive quality content which, even if sponsored, should be in line with the general orientation of the news outlet.

Within the field of SEO, analyses could be undertaken of the actual impact of links of this type in terms of improving the ranking of the websites that receive them. To do this, analytical frameworks need to be designed and employed in conjunction with such SEO tools as Sistrix, SEMrush, Ahrefs, or Majestic, among others.

\section{References}

Amazeen, Michelle A.; Muddiman, Ashley R. (2017). "Saving media or trading on trust? The effects of native advertising on audience perceptions of legacy and online news publishers". Digital journalism, v. 6, n. 2, pp. 176-195.

https://open.bu.edu/bitstream/handle/2144/27151/Amazeen_Muddiman_2017.pdf?sequence=1

https://doi.org/10.1080/21670811.2017.1293488

Amazeen, Michelle A.; Wojdynski, Bartosz W. (2018). "The effects of disclosure format on native advertising recognition and audience perceptions of legacy and online news publishers". Journalism, pp. 1-20.

https://open.bu.edu/handle/2144/27308

https://doi.org/10.1177/1464884918754829

Batsell, Jake (2018). "4 steps to bring ethical clarity to native advertising". Neiman report, September $23^{\text {rd }}$. https://niemanreports.org/articles/4-steps-to-bring-ethical-clarity-to-native-advertising

Booth, Andrew; Papaionnou, Diana; Sutton, Anthea (2012). Systematic approaches to a successful literature review. London: Sage. ISBN: 9780857021359

Brin, Sergey; Page, Lawrence (2000). "The anatomy of a large-scale hypertextual web search engine". Stanford University.

http://infolab.stanford.edu/ backrub/google.html

Cámaras-León, Nuria (2018). “Linkbuilding 2018, guía de enlazado perfecto (+12 predicciones expertos)”. Unancor, 11 January.

https://www.unancor.com/blog/guia-linkbuilding

Carlson, Matt (2014). "When news sites go native: Redefining the advertising - editorial divide in response to native advertising". Journalism, v. 16, n. 7, pp. 849-865.

https://doi.org/10.1177/1464884914545441

Cooper, Jon (2012). "Link building tactics. The complete list". Point Blank SEO, April $1^{\text {st. }}$.

http://pointblankseo.com/link-building-strategies

Cramer, Theresa (2016). "The deal with disclosure and the ethics of native advertising". Digital content text, Sept. $23^{\text {rd }}$. https://digitalcontentnext.org/blog/2016/09/06/the-deal-with-disclosure-and-the-ethics-of-native-advertising

Crowe, Anna L. (2017). "Illustrated guide to link building". Search engine journal.

https://www.searchenginejournal.com/link-building-guide

Dean, Brian (2018). "The definitive guide (2018 update)". Backlinko, March 11 1 th.

https://backlinko.com/link-building

Ferrer-Conill, Raul (2016). “Camouflaging church as state”. Journalism studies, v. 17, n. 7, pp. 904-914.

https://doi.org/10.1080/1461670X.2016.1165138

Fishkin, Rand (2016). "Targeted link building in 2016 - Whiteboard Friday". Moz, Jan 29th

https://moz.com/blog/targeted-link-building-in-2016

García-Carretero, Lucía; Codina, Lluís; Díaz-Noci, Javier; Iglesias-García, Mar (2016). “Herramientas e indicadores SEO: características y aplicación para análisis de cibermedios". El profesional de la información, v. 25, n. 3, pp. 497-504.

https://doi.org/10.3145/epi.2016.may.19 
Giomelakis, Dimitrios; Veglis, Andreas (2015). "Employing search engine optimization techniques in online news articles". Studies in media and communication, v. 3, n. 1, pp. 22-33.

https://doi.org/10.11114/smc.v3i1.683

Giomelakis, Dimitrios; Veglis, Andreas (2016). “Investigating search engine optimization factors in media websites. The case of Greece". Digital journalism, v. 4, n. 3, pp. 379-400.

https://doi.org/10.1080/21670811.2015.1046992

González-Villa, Juan (2017). “Cómo hacer link building: estrategias y ejemplos prácticos. Useo, 30 March. https://useo.es/como-hacer-link-building

Gonzalo-Penela, Carlos (2006). "Tipología y análisis de enlaces web: aplicación al estudio de los enlaces fraudulentos y de las granjas de enlaces". BiD: textos universitaris de biblioteconomia i documentación, n. 16.

http://bid.ub.edu/16gonza2.htm

Gonzalo-Penela, Carlos; Codina, Lluís; Rovira, Cristòfol (2015). "Recuperación de información centrada en el usuario y SEO: categorización y determinación de las intenciones de búsqueda en la Web”. Index comunicación, v. 5, n. 3, pp. $19-27$. http://journals.sfu.ca/indexcomunicacion/index.php/indexcomunicacion/article/view/197/175

Google (2018). Google guide making searches even easier. Search operators. http://www.googleguide.com/advanced_operators_reference.htm/

Harry, David (2013). "How search engines rank web pages". Search engine watch, Sept. $23^{\text {rd }}$. https://searchenginewatch.com/sew/news/2064539/how-search-engines-rank-web-pages

Hart, Chris (2008). Doing a literature review: Releasing the social science research imagination. London: Sage. ISBN: 978 0761959755

Kleinberg, Jon M. (1998). "Authoritative sources in a hyperlinked environment". In: Procs. of the ACM-SIAM Symposium on discrete algorithms, pp. 1-33.

https://www.cs.cornell.edu/home/kleinber/auth.pdf

Lewandowski, Dirk (2012). "A framework for evaluating the retrieval effectiveness of search engines". In: Jouis, Christophe; Biskri, Ismail; Ganascia, Jean-Gabriel; Roux, Magali. Next generation search engine: Advanced models for information retrieval. Hershey, PA: IGI Global, pp. 456-479. ISBN: 9781466603318

https://arxiv.org/pdf/1511.05817.pdf

Li, You (2017). "Contest over authority". Journalism studies, pp. 1-19. https://doi.org/10.1080/1461670X.2017.1397531

Mathiasen, Stine F. (2018). "10 quick takeaways from native advertising days 2018". Native Advertising Institute, Sept. $23^{\text {th }}$.

https://nativeadvertisinginstitute.com/blog/takeaways-native-advertising-days-2018

Monterde, Nacho (2016). "Introducción al link building". SEO azul, March $4^{\text {th }}$.

https://www.seoazul.com/introduccion-al-link-building

Pollitt, Chad (2018). The global guide to technology 2018. A resource for marketers, advertisers, media buyers, communicators, publishers and ad tech professionals.

https://nativeadvertisinginstitute.com

Publisuites (2018). "Estudio del uso de linkbuilding". Publisuite, $15^{\text {th }}$ March.

https://www.publisuites.com/blog/estudio-de-linkbuilding-publisuites

Rowe, Kevin (2018). "How link building will change in 2018". Search engine journal, Feb. $2^{\text {nd }}$. https://www.searchenginejournal.com/how-link-building-will-change/231707

Schauster, Erin E.; Ferrucci, Patrick; Neill, Marlene S. (2016). "Native advertising is the new journalism: How deception affects social responsibility". American behavioral scientist, v. 60, n. 12, pp. 1408-1424.

https://doi.org/10.1177/0002764216660135

Serrano-Cobos, Jorge (2015). "SEO: Introducción a la disciplina del posicionamiento en buscadores". Colección EPI Scholar. Barcelona: Editorial UOC. ISBN: 9788490649565

Sweetser, Kaye D.; Joo, Sun; Golan, Guy J.; Hochman, Asaf (2016). "Native advertising as a new public relations tactic". American behavioral scientist, v. 60, n. 12, pp. 1442-1457.

https://doi.org/10.1177/0002764216660138

Thelwall, Mike (2004). Link analysis: An information science approach. Amsterdam: Elsevier. ISBN: 9780120885534

Yin, Rober K. (2014). Case study research. Design and methods. Canada: SAGE. ISBN: 9781452242569 


\section{$\mathrm{Mi}$}

\section{La revista del mundo bibliotecario}

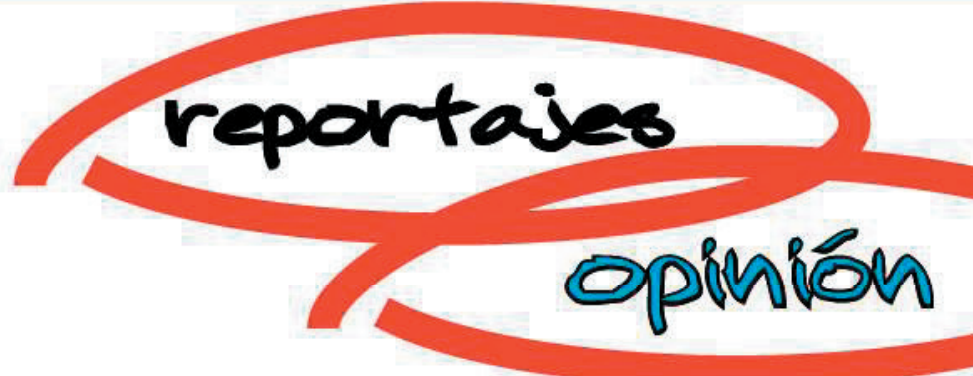

\section{biblliduses}

\section{actualidad}

\section{publicas}

\section{universitarias}

Suscríbete

952235405

www.alonsoquijano.org

belen@alonsoquijano.org 